\title{
Hubungan Efektivitas Diskusi Kelompok dengan Nilai Modul Kardiorespirasi pada Mahasiswa Angkatan 2018 di Fakultas Kedokteran Universitas Baiturrahmah
}

\author{
Maulana Rifyandi, $\mathrm{I}^{1}$, Rahmadika Akbar, $\mathrm{R}^{2}$, Nurhuda, $\mathrm{M}^{2}$ \\ ${ }^{1}$ Mahasiswa Fakultas Kedokteran Universitas Baiturrahmah \\ e-mail: \\ ${ }^{2}$ Bagian Pendidikan Kedokteran, Dosen Fakultas Kedokteran Universitas Baiturrahmah \\ e-mail: restirahmadikaakbar@gmail.com \\ ${ }^{3}$ Bagian Bedah, Dosen Fakultas Kedokteran Universitas Baiturrahmah \\ e-mail: mnurhuda@fk.unbrah.ac.id
}

\begin{abstract}
Abstrak
Latar belakang: Dalam pendidikan kedokteran, sistem student centered learning (SCL) diterapkan dengan model problem based learning (PBL). Ini merupakan inovasi dalam suatu metode pembelajaran dengan tujuan untuk melatih mahasiswa berpikir kritis, kreatif, rasional dan meningkatkan pemahaman materi serta memberikan pengalaman nyata terhadap mahasiswa salah satu metodenya yaitu diskusi kelompok. Tujuan: Mengetahui bagaimana hubungan diskusi kelompok dengan nilai Modul Kardiorespirasi mahasiswa tahun pertama di Fakultas Kedokteran Universitas Baiturrahmah. Metode: Penelitian ini merupakan penelitian analitik korelatif dengan desain cross sectional. Penelitian ini dilakukan pada mahasiswa tahun pertama pada bulan Mei 2019 dengan rumus korelatif kategorik dengan sampel sebanyak 60 orang menggunakan google formulir. Analisis data dilakukan secara univariat disajikan dalam bentuk tabel distribusi frekuensi dan analisis bivariat dengan menggunakan uji Spearman menggunakan program SPSS. Hasil: Pada penelitian ini dari 150 mahasiswa diperoleh responden sebanyak 60 orang hasil paling banyak tinggal sendiri, kontrakan atau kos yatu sebanyak 53 orang $(88,3 \%)$ dan yang paling banyak mengisi data adalah berjenis kelamin perempuan yaitu sebanyak 48 (80\%). Untuk nilai modul di dominasi oleh nilai D sebanyak 31 orang (51,3 aspek demotivational sebanyak 67\%. Kemudian hubungan efektivitas diskusi kelompok dengan nilai modul pada aspek demotivational $r=0,385$ dan $p=0,002$. Kesimpulan: Didapatkan dari tiga aspek yang terdapat pada efektifitas diskusi kelompok hanya aspek demotivational yang memiliki hubugan dengan nilai modul memiliki hubungan dan menunjukan koefisien korelasi dengan $\mathrm{p}=0,002$ dan nilai $\mathrm{r}=0,385$ maka semakin tinggi nilai aspek demotivational maka semakin tinggi tingkat kegagalan
\end{abstract}

Kata kunci : Efektivitas, aspek, kognitif, motivasi, demotivatsiona

Abstract
Backgrond: In medical education, student centered learning (SCL) system was applied with the problem based
learning (PBL) model. This is an innovation in learning methodology in order to train students thinking
critically, creatively, rationally and to increase understanding of the material and provide real experiences for
students. One of the methods is group discussion. Objective: to find out how the relationship between group
discussions with the value of the Cardiorespiration Module of first years grade students in the Faculty of
Medicine, University of Baiturrahmah. Method: This is in type of research was a correlative analytic study with
cross sectional design. This research was conducted in the class of first years grade students in May 2019 with
the samples are 60 persons and use google form that send to the group. The data analysis was univariate
presented in the form of a frequency distribution table and bivariate analysis by using the Spearman test in the
SPSS program. Result: In this study from 150 students, it was found that 60 respondents are obtained the most

Email : heme@unbrah.ac.id 
living alone, rented or boarding was around 53 people (88.3\%) and the most filling in the data was female which is 48 persons (80\%). The module value was dominated by D score of 31 people (51.3 demotivational aspects as much as 67\%. Then the relationship between the effectiveness of group discussions with the module value on the demotivational aspects $r=0.385$ and $p=0.002$. Conclusion: There is of the three aspects contained in the effectiveness of group discussion, it was only demotivational aspects which have a relationship with the module value and it showed the correlation coefficient with $p=0.002$ and the value of $r=0.385$, therefore, the more higher of demotivational value aspects, the failure rate will be higher too.

Keywords : Effectiveness, aspects, cognitive, motivation, demotivation 


\section{Pendahuluan}

Kualitas pembelajaran di Indonesia saat ini sangat memprihatinkan. Ini dibuktikan antara lain dengan data UNESCO tahun 2013 tentang peringkat index pengembangan manusia (Human Development Index), yang dilakukan oleh Education For All (EFA) Global Monitoring Report (2011): The Hidden Crisis, Armed Conflict and Education, Indonesia berada pada urutan ke 69 dari 127 negara. ${ }^{1}$ Kualitas pendidikan Indonesia saat ini masih belum sesuai harapan dibanding dengan negara-negara maju. Asisten Direktur Jenderal untuk Pendidikan dari The United Nations Educational, Scientific and Cultural Organization (UNESCO), Qian Tang, dalam peluncuran Global Education Monitoring (GEM) Report 2016 di Jakarta, menyatakan bahwa kesenjangan mutu pendidikan masih menjadi kendala banyak negara, khususnya Indonesia. Menurut data UNESCO pada tahun 2015 pendidikan di Indonesia menempati peringkat kesepuluh dari empat belas negara berkembang. ${ }^{1}$

Sistem pembelajaran perguruan tinggi di Indonesia bersifat satu arah, yaitu pemberian materi oleh dosen. Sistem pembelajaran tersebut dikenal dengan model teacher centereded learning (TCL). Dampak negatif dari sistem ini adalah menjadikan mahasiswa pasif karena hanya mendengarkan kuliah sehingga kreativitasnya kurang terpupuk atau bahkan cenderung tidak kreatif. ${ }^{2}$ Kondisi mahasiswa yang pasif menyebabkan sistem ini dirasakan kurang efektif, sehingga dosen menjadi kurang termotivasi untuk mengembangkan bahan kuliahnya. ${ }^{3}$ Sistem pendidikan dua arah adalah system student centered learning (SCL). Sistem SCL berfokus pada peserta didik, mahasiswa diarahkan untuk mencari informasi sebanyak-banyaknya dan didorong untuk melakukan diskusi dengan dosen sebagai fasilitator, bukan pemberi transfer ilmu semata. $^{4}$
Dalam dunia pendidikan kedokteran, sistem SCL diterapkan dengan model problem based learning (PBL). PBL merupakan inovasi dalam suatu metode pembelajaran dengan tujuan untuk melatih mahasiswa berpikir kritis, kreatif, rasional dan meningkatkan pemahaman materi serta memberikan pengalaman nyata terhadap mahasiswa. Proses pendekatan ini diharapkan membuat mahasiswa belajar dengan aktif untuk meningkatkan pengetahuannya dengan dosen bertindak sebagai fasilitator sehingga diharapkan kompetensi yang ada dalam diri mahasiswa dapat tergali sendiri. ${ }^{5}$

Sistem ini membagi mahasiswa menjadi kelompok-kelompok kecil yang diberi suatu kasus seputar dunia kedokteran sebagai pemicu untuk mencari informasi, lalu mahasiswa mendiskusikan pengetahuan dan informasi yang didapatkan didampingi seorang fasilitator. Sistem PBL yang memusatkan pembelajaran pada keaktifan mahasiswa telah membuktikan bahwa pemahaman mahasiswa menjadi lebih baik dan lebih mandiri. ${ }^{4}$

Salah satu metode PBL yaitu diskusi kelompok, sekelompok mahasiswa akan diberikan trigger dan mendiskusikan masalah dalam trigger tersebut. Faktor yang mempengaruhi hasil diskusi kelompok salah satunya adalah suasana diskusi kelompok yang dianggap membosankan. Hal tersebut akan berdampak negative dalam pencapaian belajar mahasiswa. Untuk itu sebaiknya fasilitator memiliki kemampuan dalam memilih metode diskusi kelompok yang tepat. Ketidaktepatan dalam penggunaan metode tersebut menimbulkan kejenuhan dalam diskusi sehingga diskusi tidak berjalan sesuai dengan harapan. ${ }^{6}$

Universitas Baiturrahmah merupakan perguruan tinggi milik swasta yang memiliki 7 program studi, salah satunya fakultas kedokteran. Sistem pembelajaran di Fakultas Kedokteran Univeritas Baiturrahmah (FK 
Unbrah) dari awal dibentuk sampai dengan 2006 menggunakan sistem konvensional. Sejak tahun 2007 hingga sekarang, FK Unbrah memakai Kurikulum Berbasis Kompetensi (KBK) dengan salah satu metodenya yaitu metode pembelajaran PBL. Pelaksanaan metode PBL dengan pendekatan Student centered, Problem based, Integrated, Community based oriented, Early clinical exposure dan self directerd learning (SPICES). ${ }^{7}$

Hasil penelitian ini sejalan dengan penelitian Vina Z. Latukonsina di Fakultas Kedokteran Universitas Patimura di Ambon menyebutkan bahwa tingkat keberhasilan diskusi kelompok sebanyak $58.94 \%$ yang dinilai dari aspek kognitif, motivasi, dan aspek demotivasi. ${ }^{9}$ Penelitian ini bertentangan dengan Cinthia. H. Riani. S di Fakultas Kedokteran Universitas Sumatera Utara yang menyebutkan bahwa diskusi kelompok dinilai kurang efektif dengan persentase $51,6 \%$ karena diskusi kelompok dianggap menambah beban dan tidak bermanfaat. $^{8} \quad$ Penelitian selanjutnya dilakukan di Universitas Andalas yang dilakukan pada 69 mahasiswa. Hasil penelitian menunjukan bahwa, sebagian besar $(66,7 \%)$ mahasiswa memberikan pernyataan keefektifan diskusi tutorial adalah tinggi sedangkan sebagian mahasiswa $(31,9 \%)$ menyatakan cukup, dan sisanya $(1,4 \%)$ menyatakan pelaksanaan diskusi tutorial kurang. 9

Nilai modul di Fakultas Kedokteran Universitas Baiturrahmah merupakan gabungan dari $20 \%$ nilai diskusi kelompok, $10 \%$ nilai praktikum, dan $70 \%$ nilai ujian tulis, penilaian dilakukan untuk menilai aspek kognitif, psikomotor dan afektif dengan berbagai modal dalam penilaian diharapkan penilaian tersebut reliabel. ${ }^{7}$

\section{Metode Penelitian}

Penelitian ini mengenai hubungan efektivitas diskusi kelompok dengan nilai Modul
Kardiorespirasi pada mahasiswa Angkatan 2018 di Fakultas Kedokteran Universitas Baiturrahmah. Penelitian analitik korelatif dengan desain cross sectional. Sampel penelitian ini adalah bagian dari populasi mahasiswa angkatan 2018 Fakultas Kedokteran Universitas Baiturrahmah yang memenuhi kriteria inklusi dan eksklusi. Pengambilan data menggunakan metode yaitu convenience sampling

\section{HASIL}

Berdasarkan penelitian yang dilakukan, diperoleh gambaran karakteristik dari 60 responden seperti pada tabel berikut.

TABEL 1. KARAKTERISTIK RESPONDEN Berdasarkan TeMPat Tinggal DAN Jenis KELAMIN

\begin{tabular}{lcc}
\hline \multicolumn{1}{c}{ Karakteristik } & n & \% \\
\hline Berdasarkan Tempat Tinggal & & \\
Tinggal Bersama orang tua & 7 & 11,7 \\
Tinggal kontrakan atau kos & 53 & 88,3 \\
Berdasarkan jenis kelamin & & \\
$\quad$ - Laki-laki & 12 & 20 \\
$\quad$ - Perempuan & 48 & 80 \\
\hline
\end{tabular}

Berdasarkan Tabel 1 dari 60 responden diperoleh hasil paling banyak tinggal sendiri, kontrakan atau kos yatu sebanyak 53 orang $(88,3 \%)$ dan yang paling banyak mengisi data adalah berjenis kelamin perempuan yaitu sebanyak $48(80 \%)$.

TABEL 2. Nilai ModUl Kardiorespirasi FAKULTAS KEDOKTERAN UNIVERSITAS BAITURRAHMAH PADANG ANGKATAN 2018

\begin{tabular}{llll}
\hline No & \multicolumn{1}{c}{$\begin{array}{c}\text { Nilai Modul } \\
\text { Kardiorespirasi }\end{array}$} & n & \% \\
\hline 1 & A = Sangat Cemerlang & 0 & 0 \\
2 & A- = Cemerlang & 0 & 0 \\
3 & B+ = Sangat Baik & 5 & 8,3 \\
4 & B = Baik & 4 & 6,7 \\
5 & B- = Hampir Baik & 3 & 5 \\
6 & C+ = Lebih & 6 & 10 \\
7 & C = Cukup & 9 & 15 \\
8 & D = Hampir Cukup & 31 & 51,7 \\
9 & E = Gagal & 1 & 1,7 \\
10 & Bl= Ulang Program & 1 & 1,7 \\
\hline
\end{tabular}

Berdasarkan Tabel 2 diperoleh hasil dari 
nilai Modul Kardiorespirasi Fakultas Kedokteran Universitas Baiturrahamah angkatan 2018 yaitu dari 60 responden tidak ada yang mendapat nilai $\mathrm{A}$ dan $\mathrm{A}-$, nilai didominasi nilai $\mathrm{D}$ sebanyak 31 orang $(51,7 \%)$, dan BL sebanyak 1 orang $(1,7 \%)$

Tabel 3. Hasil Penelitian Aspek Kognitif

\begin{tabular}{cccccc}
\hline \multirow{2}{*}{ No } & \multirow{2}{*}{ Pernyataan } & \multicolumn{2}{c}{ Baik } & \multicolumn{2}{c}{ Kurang } \\
\cline { 3 - 6 } & & n & \% & n & \% \\
\hline 1 & P1 & 45 & 75 & 15 & 25 \\
2 & P2 & 48 & 80 & 12 & 20 \\
3 & P3 & 54 & 90 & 6 & 10 \\
4 & P4 & 51 & 85 & 9 & 15 \\
5 & P5 & 56 & 93 & 4 & 7 \\
6 & P6 & 52 & 87 & 8 & 13 \\
7 & P7 & 55 & 92 & 5 & 8 \\
\hline
\end{tabular}

Berdasarkan tabel 3 data paling banyak disetujui yaitu pernyataan (P5) dalam kelompok tutorial, saya belajar banyak dari kontribusi (sumbangsih) sesama anggota kelompok adalah sebanyak 56 orang (93\%) dan pernyataan (P7) anggota-anggota kelompok saling membangun pembahasan berdasarkan argumen masing-masing anggota adalah sebnyak 55 orang (92\%). Yang paling sedikit dari persetujuan pernyataan yaitu sebanyak 45 orang $(75 \%)$ pada pernyataan (P1) Selama tutorial berlangsung, materi yang dibahas sebagian besar dijelaskan oleh peserta secara individual.

Tabel 4. Hasil Penelitian Aspek Motivasional

\begin{tabular}{cccccc}
\hline \multirow{2}{*}{ No } & \multirow{2}{*}{ Pernyataan } & \multicolumn{2}{c}{ Baik } & \multicolumn{2}{c}{ Kurang } \\
\cline { 2 - 6 } & & n & \% & n & \% \\
\hline 1 & P8 & 55 & 92 & 5 & 8 \\
2 & P9 & 49 & 82 & 11 & 18 \\
3 & P10 & 45 & 75 & 15 & 25 \\
4 & P11 & 52 & 87 & 8 & 13 \\
5 & P12 & 54 & 90 & 6 & 10 \\
6 & P13 & 54 & 90 & 6 & 10 \\
7 & P14 & 52 & 87 & 8 & 13 \\
\hline
\end{tabular}

Berdasarkan tabel 4 dari ketujuh pernyataan paling banyak disetujui yaitu pernyataan (P12) kelompok tutorial memberi pengaruh positif terhadap komitmen dan usaha akademik saya dan ketertarikan saya terhadap materi yang dipelajari meningkat akibat diskusi dalam kelompok tutorial adalah sebanyak 54 orang $(90 \%)$. Yang paling sedikit dari persetujuan pernyataan yaitu sebanyak 45 orang $(75 \%)$ pada pernyataan (P10) saya menjadi lebih tanggap dan sensitif terhadap kebutuhan anggota lain dalam kelompok selama kerja kelompok.

Tabel 5. Hasil Penelitian Aspek DEMOTIVASIONAL

\begin{tabular}{cccccc}
\hline \multirow{2}{*}{ No } & \multirow{2}{*}{ Pernyataan } & \multicolumn{2}{c}{ Baik } & \multicolumn{2}{c}{ Kurang } \\
& & n & \% & n & \% \\
\hline 1 & P15 & 40 & 67 & 20 & 33 \\
2 & P16 & 27 & 45 & 33 & 55 \\
3 & P17 & 24 & 40 & 36 & 60 \\
4 & P18 & 16 & 27 & 44 & 73 \\
5 & P19 & 29 & 48 & 31 & 52 \\
\hline
\end{tabular}

Berdasarkan tabel 5 dilihat dari jumlah pernyataan pada aspek demotivational, (73\%) mahasiswa paling banyak tidak setuju dengan pernyataan (P18) beberapa anggota kelompok memberi pengaruh negatif terhadap kontribusi anggota kelompok lainnya sedangkan pernyataan yang paling banyak disetujui (67\%) pada pernyataan (P15) Selama berlangsungnya tutorial, beberapa anggota kelompok hanya berkontribusi sedikit dalam diskusi kelompok.

TABEl 6. HubUngan DisKuSI KelompoK DENGAN NiLAI MOdUL

\begin{tabular}{ccccc}
\hline $\begin{array}{c}\text { Tutorial Group } \\
\text { Efektiveness } \\
\text { Instrument }\end{array}$ & Kognitif & $\begin{array}{c}\text { Motiva } \\
\text { tional }\end{array}$ & $\begin{array}{c}\text { Demotiva } \\
\text { tional }\end{array}$ \\
\hline \multirow{2}{*}{$\mathrm{B}+$} & $\mathrm{P}$ & 0,265 & 0,398 & 0,002 \\
& $\mathrm{R}$ & $-0,147$ & $-0,111$ & 0,385 \\
$\mathrm{~B}$ & $\mathrm{P}$ & 0,265 & 0,398 & 0,002 \\
& $\mathrm{R}$ & $-0,147$ & $-0,111$ & 0,385 \\
$\mathrm{~B}-$ & $\mathrm{P}$ & 0,265 & 0,398 & 0,002 \\
& $\mathrm{R}$ & $-0,147$ & $-0,111$ & 0,385 \\
$\mathrm{C}+$ & $\mathrm{P}$ & 0,265 & 0,398 & 0,002 \\
& $\mathrm{R}$ & $-0,147$ & $-0,111$ & 0,385 \\
$\mathrm{C}$ & $\mathrm{P}$ & 0,265 & 0,398 & 0,002 \\
& $\mathrm{R}$ & $-0,147$ & $-0,111$ & 0,385 \\
$\mathrm{D}$ & $\mathrm{P}$ & 0,265 & 0,398 & 0,002 \\
& $\mathrm{R}$ & $-0,147$ & $-0,111$ & 0,385 \\
$\mathrm{E}$ & $\mathrm{P}$ & 0,265 & 0,398 & 0,002 \\
& $\mathrm{R}$ & $-0,147$ & $-0,111$ & 0,385 \\
$\mathrm{BL}$ & $\mathrm{P}$ & 0,265 & 0,398 & 0,002 \\
& $\mathrm{R}$ & $-0,147$ & $-0,111$ & 0,385 \\
\hline
\end{tabular}


Berdasakan tabel 6 data yang sudah didapatkan nilai $\mathrm{p}$ dan nilai $\mathrm{r}$ berdasarkan masing masing aspek, aspek kognitif $\mathrm{r}=$ $-0,147$ dan $\mathrm{p}=0,265$, pada aspek motivational $\mathrm{r}=-0,111$ dan $\mathrm{p}=0,398$, sedangkan pada demotivational $\mathrm{r}=0,385$ dan $\mathrm{p}=0,002$.

\section{Pembahasan}

\section{A. Karakteristik Mahasiswa}

\section{1) Berdasarkan jenis kelamin}

Berdasarkan pendataan yang paling banyak mengisi kuesioner dari 60 sampel adalah perempuan sebanyak 48 orang $(80 \%)$ dan sisannya adalah laki laki 12 orang (20\%). Sama halnya dengan penelitian yang dilakukan V. Pioh yang paling banyak mengisi kuesioner ini adalah perempuan yaitu sebesar (60\%) dan (40\%) lainnya adalah laki laki.

Dari 150 orang angkatan 2018, 140 orang $(77,8 \%)$ adalah berjenis kelamin perempuan dan sisannya 40 orang $(22,2 \%)$ berjenis kelamin laki-laki. Yang paling banyak mengisi kuesioner untuk penelitian kali ini adalah perempuan. Menurut peneliti, mungkin ini terjadi karena berbagai hal, salah satunnya yaitu karena rasa segan dari junior perempuan terhadap senior laki- laki, atau mungkin karena ketika peneliti membagikan kuesioner di group "line" angkatan mereka, yang melihat kuesioner tersebut lebih banyak adalah perempuan.

Jenis kelamin adalah identitas biologis, yang terdiri dari perempuan dan laki- laki. Secara umum diasumsikan bahwa perempuan memiliki motif berprestasi lebih rendah dibandingkan laki-laki, sehingga motivasi belajar perempuan lebih rendah dibanding laki-laki. Hal ini disebabkan oleh pola pengasuhan dari orang tua kepada anak lakilaki dan anak perempuan. Anak laki-laki didorong orang tua untuk menampilkan keunggulan dan diberikan kebebasan lebih awal dibandingkan anak perempuan.
Sebaliknya, anak perempuan cenderung lebih banyak dibantu dan diberikan perlindungan secara berlebihan oleh orangtua. Pola asuh seperti ini tentunya akan menghambat motif berprestasi, sehingga prestasi anak laki-laki lebih tinggi dibanding anak perempuan. ${ }^{35}$

\section{2) Berdasarkan tempat tinggal}

Berdasarkan penelitan diperoleh hasil dari 60 responden yang paling banyak mengisi kuesioner adalah mahasiswa yang tinggal sendiri atau kontrakan (88,3\%). Sejalan dengan penelitian sebelumnnya dengan Universitas di Aceh dengan sampel 112 orang yaitu yang tinggal Bersama orang tua sebanyak 65 orang $(58 \%)$.

Faktor yang ada pada diri organisme tersebut yang disebut faktor individual. Faktor individual adalah faktor kematangan atau pertumbuhan, faktor kecerdasan atau inteligensi faktor tugas, faktor motivasi, faktor pribadi. Faktor yang ada di luar individu atau faktor sosial adalah faktor keluarga atau keadaan rumah tangga, suasana dan keadaan keluarga yang bermacammacam turut menentukan bagaimana dan sampai di mana belajar dialami anak-anak. ${ }^{36}$ Ada keluarga yang memiliki cita-cita tinggi bagi anak-anaknya. Ada juga faktor yang memengaruhi hasil belajarnya, seperti kelelahan karena jarak rumah dan sekolah cukup jauh, tidak ada kesempatan karena sibuk bekerja, serta pengaruh lingkungan yang buruk yang terjadi di luar kemampuannya. $^{36}$

\section{B. Kuesioner TGEI}

\section{1) Aspek kognitif}

Berdasarkan data yang ada lebih banyak aspek kognitif berada pada pernyataan dengan penilaian baik (86 \%) atau dapat dikatakan penilaian efektivitas diskusi kelompok di lihat dari aspek kognitif sebagian besar efektif. Dari ketujuh pernyataan paling banyak disetujui yaitu pernyataan dalam kelompok tutorial, saya belajar banyak dari kontribusi (sumbangsih) 
sesama anggota kelompok sebanyak 56 orang (93\%) dan pernyataan anggotaanggota kelompok saling membangun pembahasan berdasarkan 58 argumen masing-masing anggota sebanyak 55 orang (92\%). Yang paling sedikit dari persetujuan pernyataan yaitu sebanyak 45 orang $(75 \%)$ pada peryataan Selama tutorial berlangsung, materi yang dibahas sebagian besar dijelaskan oleh peserta secara individual.

Hasil penelitian ini sejalan dengan penelitian V. Pioh di Universitas Samratulangi Berdasarkan data yang ada lebih banyak aspek kognitif berada pada pernyataan dengan penilaian baik $(87,5 \%)$ atau dapat dikatakan penilaian kelompok diskusi tutorial PBL dari aspek kognitif sebagian besar efektif . Dari ketujuh pernyataan untuk menilai aspek kognitif, seluruh sampel (100\%) setuju dengan pernyataan nomor 7 Sebaliknya, pernyataan yang paling banyak tidak disetujui (15\%) mahasiswa ada pada pernyataan selama tutorial berlangsung, materi yang dibahas sebagian besar dijelaskan oleh peserta secara individual. ${ }^{5}$ Evaluasi diri mahasiswa terhadap aspek kognitif dinilai dari pernyataan 1 s/d 7 . Sebagian besar mahasiswa memberikan evaluasi penilaian yang baik pada segi aspek kognitif pada saat berlangsungnya PBL yaitu $79,58 \%{ }^{8}$

Aspek kognitif menjadi aspek utama dalam banyak kurikulum pendidikan dan menjadi tolok ukur penilaian perkembangan mahasiswa. Kognitif yang berasal dari bahasa latin cognitio memiliki arti pengenalan, yang mengacu kepada proses mengetahui maupun kepada pengetahuan itu sendiri. ${ }^{8}$

Terdapat 6 unsur dalam aspek kognitif yaitu Pengetahuan (knowledge) adalah kemampuan seseorang untuk mengingat kembali (recall) atau mengenal kembali tentang nama, istilah, ide, gejala, rumusrumus dan sebagainya tanpa mengharapkan kemampuan untuk menggunakannya.
Pemahaman (comprehension) adalah kemampuan seseorang untuk mengerti atau memahami sesuatu setelah sesuatu itu diketahui dan diingat, penerapan (application) adalah kesanggupan seseorang untuk menerapkan atau menggunakan ideide, rumus-rumus, teori-teori, dan sebagainya, dalam situasi yang baru dan kongkrit, analisis (analysis) adalah kemampuan seseorang untuk merinci atau menguraikan suatu bahan atau keadaan menurut bagian-bagian yang lebih kecil dan mampu memahami hubungan diantara bagian-bagian atau faktor-faktor yang satu dengan faktor-faktor lainnya, sintesis (synthesis) adalah kemampuan berpikir yang merupakan kebalikan dari proses berpikir analisis atau merupakan suatu proses yang memadukan bagian- bagian atau unsur-unsur secara logis, sehingga menjelma menjadi suatu pola yang berstruktur atau berbentuk pola baru, penilaian (evaluation) adalah kemampuan seseorang untuk membuat pertimbangan terhadap suatu situasi, nilai atau ide. ${ }^{37}$

\section{2) Aspek Motivational}

Berdasarkan data yang ada lebih banyak aspek motivational berada pada pernyataan dengan penilaian baik (86\%) atau dapat dikatakan penilaian efektivitas diskusi kelompok di lihat dari aspek motivational sebagian besar efektif. Dari ketujuh pernyataan paling banyak disetujui yaitu pernyataan: "Kelompok tutorial merangsang aktivitas belajar mandiri saya dan pernyataan kelompok tutorial memberi pengaruh positif terhadap komitmen dan usaha akademik saya", sebanyak 54 orang $(90 \%)$. Yang paling sedikit dari persetujuan pernyataan yaitu sebanyak 45 orang $(75 \%)$ pada peryataan: "Saya menjadi lebih tanggap dan sensitif terhadap kebutuhan anggota lain dalam kelompok selama kerja kelompok".

Penelitian ini sejalan dengan Mewo mengatakan efektivitas kelompok diskusi tutorial dilihat dari aspek motivasi yaitu baik dengan hasil persentase $92,5 \%$. Terdapat 
97\% mahasiswa yang setuju pada pernyataan: "Saya merasa sebagai anggota kelompok, bertanggungjawab terhadap kemajuan kelompok". Pernyataan yang paling banyak tidak disetuju $(15 \%)$ terdapat pada pernyataan: "Diskusi kelompok tutorial merangsang teman-teman kelompok saya untuk mengupayakan kemampuan terbaik mereka".

Motivasi diambil dari kata motion yang artinya gerakan dan dibawahnya di jabarkan lagi dengan kata motivate yang artinnya mendorong, menggerakan, menyebabkan. ${ }^{38}$ Motivasi seseorang terdiri dari dua aspek, yaitu internal dan eksternal. Motivasi internal jika seseorang melakukan sesuatu memang karena hal itu sendiri (sebuah tujuan itu sendiri), bukan karena dipengaruhi oleh orang lain maupun faktor lain. Sedangkan, motivasi ekstrinsik yaitu melakukan sesuatu untuk mendapatkan sesuatu yang lain (sebuah cara untuk mencapai suatu tujuan tertentu), seperti adanya insentif, penghargaan, maupun hukuman. ${ }^{39}$

\section{3) Aspek Demotivational}

Pernyataan demotivational atau pernyataan nomor 15-19 merupakan bentuk pernyataan terbalik atau pernyataan negatif untuk menilai efektivitas kelompok diskusi kelompok. Pada aspek demotivational terdapat $67 \%$ penilaian baik terhadap efektivitas diskusi kelompok dan hanya $33 \%$ saja yang kurang, di lihat dari jumlah pernyataan pada aspek demotivational, $73 \%$ mahasiswa paling banyak tidak setuju dengan pernyataan: "Beberapa anggota kelompok memberi pengaruh negatif terhadap kontribusi anggota kelompok lainnya", sedangkan pernyataan yang paling banyak disetujui (67\%) pada pernyataan: "Selama berlangsungnya tutorial, beberapa anggota kelompok hanya berkontribusi sedikit dalam diskusi kelompok".

Penelitian yang dilakukan Vina Z. juga mendapatkan hasil sama yaitu kebalikan dari kedua aspek diatas, persepsi mahasiswa terhadap aspek demotivational sebagian besar kurang baik, yaitu 79,73\%. ${ }^{8}$

Aspek demotivational berarti adalah aspek yang terdiri dari dua kata de dan motivational, de artinnya tidak dan motivasi artinya seseorang yang ingin melakukan sesuatu karna ada alasan, jadi demotivational adalah sebuah aspek yang bertentangan dengan motivasi. ${ }^{26}$

\section{Hubungan Efektivitas Diskusi Kelompok dengan Nilai Modul Kardiorespirasi}

Berdasarkan penelitian efektivitas diskusi kelompok terbagi atas tiga aspek yaitu aspek kognitif, aspek motivational dan aspek demotivational, diperoleh hasil uji statistik (spearman rho) mendapatkan hasil untuk aspek kognitif $p=0,265$, maka dapat disimpulkan bahwa tidak terdapat hubungan aspek kognitif dengan nilai Modul Kardiorespirasi pada angkatan 2018. Hubungan ini menunjukan korelasi (r) = $-0,147$, berarti tingkat korelasi variabel dalam kategori tidak berhubungan dengan dengan arah negative. Untuk aspek motivasional nilai $\mathrm{p}=0,398$, maka dapat disimpulkan bahwa tidak terdapat hubungan aspek kognitif dengan nilai modul kardiorespiras pada angkatan 2018. Hubungan ini menunjukan korelasi (r) = $-0,111$, berarti tingkat korelasi variabel dalam kategori tidak berhubungan dengan dengan arah negative, sedangkan untuk aspek demotivational nilai $\mathrm{p}=0,002$, maka dapat disimpulkan bahwa aspek demotivational dengan nilai modul, keeratan hubungan kedua variabel tersebut menunjukan koofesien korelasi $(r)=0,385$ berarti tingkat korelasi variabel dalam kategori lemah dengan arah positif.

Motivasi belajar mahasiswa masih berkaitan dengan aspek demotivational. Untuk pernyataan aspek demotivational lebih membahas mengenai hal-hal yang menghambat motivasi belajar mahasiswa dan keberhasilan kelompok. Pernyataan demotivational merupakan bentuk 
pernyataan negatif. Pembahasan untuk aspek demotivational erat kaitannya dengan motivasi mahasiswa yang muncul dari luar diri atau ekstrinsik. Motivasi yang muncul dari luar tidak akan bertahan bila dipengaruhi oleh beberapa faktor yang menghambat. Motivasi belajar mahasiswa dipengaruhi oleh hal apa yang ingin dipelajari. ${ }^{40}$ Apabila ada dorongan atau keingingan untuk mempelajari sesuatu maka mahasiswa akan bekerja keras sehingga mencapai apa yang diinginkannya. Bila tidak didasari oleh keinginan untuk apa yang hendak dipelajari, maka hal itulah yang mendukung aspek demotivational mempengaruhi hubungan efektivitas diskusi kelompok dengan nilai modul yang rendah, pada angkatan 2018 dilihat dari nilai kardiorespirasi di dominasi oleh nilai D, peneliti mengansumsikan ini lah yang mengakibatkan adannya hubungan demotivational dengan nilai Modul Kardiorespirasi.

\section{KeSIMPUlaN}

Berdasarkan hasil penelitian tentang hubungan efektifitas diskusi kelompok dengan nilai Modul Kardiorespirasi pada angkatan 2018 di Fakultas Kedokteran Universitas Baiturrahmah, maka dapat disimpulkan bahwa :

1. Dari penelitian yang sudah dilakukan, dapat disimpulkan dari 60 sampel yang paling banyak mengisi kuesioner adalah mahasiswa/i yang tinggal sendirian atau kos (kontrakan) yaitu sebanyak 53 orang $(88,3 \%)$, dan yang berjenis kelamin perempuan yaitu sebanyak 48 orang $(80 \%)$.

2. Nilai Modul Kardiorespirasi didominasi nilai D sebanyak 31 orang $(51,7 \%)$.

3. Dari hasil efektifitas diskusi kelompok aspek kognitif pernyataan saya belajar banyak dari kontribusi (sumbangsih) sesama anggota kelompok adalah sebanyak 56 orang (93\%), aspek motivational, pernyataan: "kelompok tutorial memberi pengaruh positif terhadap komitmen dan usaha akademik saya dan ketertarikan saya terhadap materi yang dipelajari meningkat akibat diskusi dalam kelompok tutorial" adalah sebanyak 54 orang (90\%), dan aspek demotivatinal pernyataan: "Beberapa anggota kelompok memberi pengaruh negatif terhadap kontribusi anggota kelompok lainnya sedangkan pernyataan yang paling banyak disetujui (67\%).

4. Aspek demotivational dengan nilai modul memiliki hubungan dengan $p=0,002$ dan nilai $\mathrm{r}=0,385$ menunjukan semakin tinggi nilai aspek demotivational semakin tinggi tingkat kegagalan.

\section{SARAN}

1. Bagi mahasiswa diharapkan dapat mempersiapkan diri dengan baik sebelum melaksanakan diskusi kelompok, agar dapat berkontribusi dengan baik dan dapat meningkatkan keefektivitasan diskusi kelompok.

2. Bagi institusi daiharapkan dapat memperhatikan hal-hal yang dapat mempengaruhi efektivitas diskusi kelompok dan dapat mengantisipasinya

3. Diperlukan penelitian lebih lanjut tentang faktor-faktor lain yang dapat mempengaruhi efektivitas diskusi keompok, contohnya keaktifan, dari trigger, dan fasilitator

\section{Daftar Pustaka}

[1] Kebudayaan KKBPM dan. Indonesia Peringkat ke-57 EDI dari 115 Negara Tahun 2014. HUMASNEW.

[2] Ardian A, Munadi S. Pengaruh Strategi Pembelajaran Student-Centered Learning Dan Kemampuan Spasial. J Pendidik Teknol dan Kejuru. 2015;22(4):454-466.

[3] Kedokteran NP. Kematangan refleksi diri dosen sebagai tutor terhadap paradigma. 2017;6(1).

[4] Fauziah Nuraini Kurdi. Penerapan StudentCentered Learning Dari Teacher-Centered Learning Mata Ajar Ilmu. Forum Kependidikan. 2009;28(2):108-113.

[5] Pioh VE, Mewo Y, Berhimpon S. Efektivitas kelompok diskusi tutorial problem based learning di Fakultas Kedokteran Universitas Sam Ratulangi. e-Biomedik (eBm). 2016;4(1). doi:10.1055/s-0034-1366097 
[6] Lailatus SS, Mochammad, Ardian Suryaji SNA, Poppy Rahmatika Primandiri AMS. Efektifitas Model Pembelajaran Problem Based Learning (PBL) Berbasis Local Materials terhadap Keterampilan Metakognisi, Keterampilan Inkuiri dan Keterampilan Sosial Siswa Kelas VIII SMP Pawyatan Daha 2 Kediri. J Berbas LOCAL Mater. 2015;2(1):501-507.

[7] Rektor Universitas Baiturrahmah. Pedoman Kurikulum Universitas Baiturrahmah. Padang: Universitas Baiturrahmah; 2018.

[8] Latukonsina VZ. Evaluasi Diri Problem Based Learning (PBL) Pada Blok Biomedik 5 Mahasiswa Semester 2 Fakultas Kedokteran Universitas Pattimura. Molucca Medica. 2012;5(1):24-31.

[9] Setiawan E. Kamus Besar Bahasa Indonesia (KBBI). Kemendikbud. https://www.kbbi.web.id/mahasiswa. Published 2018. Accessed January 29, 2019.

[10] Yusniah. Hubungan Pola Asuh Orang Tua Dan Prestasi Belajar Mahasiswa. jakarta; 2008.

[11]Purwanto. Evaluasi Hasil Belajar. (Belajar P, ed.). Yogyakarta: pustaka belajar; 2011.

[12] Sudiyono A. Pengantar Evaluasi Pendidikan. Jakarta: pt raja grafinda persada; 2009.

[13] Latukonsina VZ. Evaluasi diri Problem Based Learning (PBL) pada blok biomedik mahasiswa semester 2 Fakultas Kedokteran Universitas Pattimura. J Kedokt dan Kesehat. 2012;5(1):2431 